Cornell Law Library Scholarship@Cornell Law: A Digital Repository

Cornell Law Faculty Publications

$1-1-2006$

\title{
Institutional Fixes versus Fixed Institutions
}

Robert C. Hockett

Cornell Law School, rch37@cornell.edu

Follow this and additional works at: http://scholarship.law.cornell.edu/lsrp_papers

Part of the Law and Society Commons

\section{Recommended Citation}

Hockett, Robert C., "Institutional Fixes versus Fixed Institutions" (2006). Cornell Law Faculty Publications. Paper 116.

http://scholarship.law.cornell.edu/lsrp_papers/116

This Article is brought to you for free and open access by Scholarship@Cornell Law: A Digital Repository. It has been accepted for inclusion in Cornell Law Faculty Publications by an authorized administrator of Scholarship@Cornell Law: A Digital Repository. For more information, please contact jmp8@cornell.edu. 


\title{
Institutional Fixes versus Fixed Institutions
}

\author{
Robert Hockett $\dagger$
}

\section{Comment on Richard Miller's Global Institutional Reform and Global Social Movements: From False Promise to Realistic Hope}

Okay. It looks as though much, though not all, of what I have to say is either going to reinforce or to complement what Dick Arneson has just said. So I'll try to be (uncharacteristically) brief. I'll also place most of my emphasis on those points that complement, rather than those that simply reinforce, Dick's helpful remarks.

The first point I'll make is preliminary in character. It is that Professor Miller's paper does, I believe, constitute a helpful reminder to us all. We do well always to bear in mind that simply more international institutions, or institutions simply with more nominal authority, will not of themselves suffice to better the world. Much more is needed, and it is grossly to oversimplify to think or claim otherwise. It can, moreover, be positively harmful, in a variety of ways, to fixate uniquely upon institutional solutions to all perceived global problems. There is no such "fix." For we must, at a minimum, bear in mind the critical roles played by what Professor Miller calls "social movements", in addition to the roles played by institutions. So two cheers - at the least - for what Dick Miller has just argued.

But now, on the other hand, I think that it is also critical - and I want to emphasize that I don't take Professor Miller to be claiming the contrary, I'm simply ensuring that no one takes him for doing so - that, for symmetrical reasons, we must not advocate a global social movement "fix" either. We do best, as Dick Arneson has suggested, to consider in tandem what I shall emphasize are the mutually complementary roles played by both institutions and movements. Indeed, in this connection I think that we might even extend a bit from what Dick Arneson has said: We do well to consider what seems in fact to be a cluster of essential relations between movements and institutions. The two things are deeply connected. Indeed there is even a sense in which we might think of movements and institutions nearly in the way that we think of left and right, up and down, or perhaps yet more aptly, means and ends. I think in fact that we can understand these

$\dagger$ Assistant Professor of Law, Cornell University Law School. Many thanks to Dick Arneson, Jack Barcelo, Christian Barry, Dick Miller, Sanjay Reddy, and Joel Trachtman for helpful discussion both of the matters briefly addressed in this essay, and of additional, related matters over the course of the past several years.

39 CORNELl INT'L L.J. 537 (2006) 
things fully and accurately only when we understand them in relation to one another. Let me draw out that prospect a bit.

There are at least two interlinked senses, I believe, in which there is deep complementarity or symbiosis between movements and institutions. First, an institution can usefully be viewed as a more thoroughly and enduringly organized, rationalized, or routinized form or outcome of a movement itself. Movements are typically geared towards, and indeed teleologically best understood partly by reference to, institutional outcomes: They aim at the creation of institutions, or the reform of institutions, or at the development of various arrangements which effectively amount to one or another form of "harder" or "softer" institution, or even at gradually themselves morphing into institutions.

A brief thought-experiment, I believe, will preliminarily corroborate my claim: Try to imagine any cluster of purposive actions taken by any group of people in respect of some policy or set of policies - i.e., try to imagine anything that you would count as a "movement" - that cannot be said to be animated by and indeed even self-understood in significant part by reference to one or more of the aims I have listed in the foregoing paragraph. My guess is that you'll come up empty. My guess is you wouldn't call it a "movement" were it not to be institution-connected in one or more of those ways I've just listed.

Now turn from preliminary thought-experimentation to the dynamics of particular institutions and movements. In the interest of time, I'll confine myself here to a straightforward domestic example from the large set of actual movements of times past and resultant institutions of times present. So consider, if you will, the history of the American labor movement - a movement whose history is particularly instructive, I think, for our conference's purposes. For our next panel, as you know, will concern itself with the task of describing and prescribing in relation to the now rapidly changing global labor regime and its justice significance.

So, in the domestic case, say we're in early to mid-nineteenth century America. Cities are crowding with new immigrants. Presently available land is all owned. Livings can be had for the most part only by laboring for firms owned by comparatively few others. Working conditions, in consequence, are growing quite harsh for the many who don't own.

In response to these developments, first there is a gradually growing discontent, then mounting dissent, among working folk. They feel that something's gone wrong. They sense that somehow they're being exploited or unjustly done-by. Or perhaps they know only that they are miserable.

At length these people begin to talk to one another about the mentioned developments. They commiserate and share complaints with each other, informally at first and then maybe in somewhat more regularized or even quasi-formal "gripe sessions." Over time they begin gradually to converge upon a common set of such complaints, a common manner of describing and framing them, perhaps even a common way of articulating what is wrong and of diagnosing what accounts for it. In effect, these peo- 
ple have begun jointly to theorize their experiences, and to systematize thought as to what they might rightfully do to improve their own lots.

Little by little, then, these people begin to think, then to "move," in common. A shared set of concerns and shared language have that effect, after all: They order experience, they regularize things. So our laborers come gradually to constitute "a movement" - "the labor movement." But this means that they coalesce into a kind of institution or proto-institution, does it not? At first an institution is but the loose sense in which a language, or an ideology, can be said to be an institution. A shared system of interpretation of objective circumstances. But then, gradually, an institution in the "harder" sense, pursuant to which distinct responsibilities are allocated to distinct individuals who combine efforts in pursuit of a shared set of objectives.

The movement gradually takes the form of "labor unions," i.e., "hard" institutions, which provide the movement with focus and stable direction, via more or less stable "agendas" (not to mention mobilized resources), and in so doing prevent efforts from being dissipated, wasted, unfocused and thus ineffectual. Indeed, these unions then come to be seen almost as ends in themselves, or at any rate as indispensable intermediate ends - means to the ultimate end of improving labor's lot. Hence the emphasis in labor unions on the importance of union, unity, and solidarity itself. One can indeed view an institution as an incorporation - an embodiment - of precisely such solidarity. It is the forging of one out of many - a case of $e$ pluribus unum.

Now the reasons that "the labor movement" gradually took on a more "hard" institutional form, I think, include among them (though I don't think they're exhausted by) all the reasons that Dick Miller himself has pointed out in defining what an institution is. All of the advantages that Professor Miller notes institutions possess, are among what I think to be the larger, more plenary, set of reasons that movements like the labor movement tend to coalesce over time into institutions. But the full set of reasons also includes additional explanations rooted in the essential structure - the "group-teleology," so to speak - of collective-ends-pursuit itself, as just suggested in my quaint domestic example. One might accordingly quibble a bit with Dick's characterization of institutions - his proffered account of institutions and their nature. I don't wish to make much of that here, however, for I don't believe that Dick meant his characterization of institutions to be exhaustive. And my present point in any event is no more than that the dynamic pursuant to which diffuse concerned persons coalesce into movements is the same dynamic pursuant to which movements, in turn, coalesce into institutions. Yet, I do believe that the fact of that dynamic's full sweep - the fact that institutions are the consummations of movements - can be obscured if we do not bear in mind some of the subtler characteristics of institutions, the progressive stages of institutional development, and the many subtle ways in which institutional forms vary over time and across purposes. 
I won't belabor this point, but note: There really is a continuum of institution-types, is there not, moving from the "softer" to the "harder"? In the terms of my labor movement story, for example, the institutional continuum runs from, at the "soft" end, occasionally shared gripes by commiserating laborers, to more regular "gripe sessions" by the same, to spontaneous acts of protest by laborers acting in concert with one another, to carefully planned protests, to fuller agenda formation, to a "labor movement" whose internal "division of labor" gradually develops along more specialized lines, and finally to full-blown, institutionalized labor unions with elected leaders and treasuries and office space, etc. But if this is the case, then movements and institutions do not seem to be alternatives so much as they are looser or tighter versions of what at bottom is one thing, with the institution being the endpoint toward which movements "move."

One more example might be more familiar to those of us who weren't around during the heyday of the American labor movement: Think of MoveOn.Org, whose very name could scarcely be more felicitous for present purposes. Now if I recall correctly, MoveOn began as a spontaneous, web-based protest against the childish public obsession with President Clinton's private life, as cynically fomented and exploited by Clinton's right-wing enemies whose own private lives were no cleaner than Clinton's. It was a grassroots "movement." If you visit the MoveOn website now, however, I think you will find that, though still voluntaristic and grass-rootsy in nature, it's a rather different - a much "tighter" and better developed organization than it began as. It's now a full-blown "institution" by anybody's - even Dick Miller's for present purposes minimalist - reckoning. And I think it is altogether natural that it would have become such, pursuant precisely to the natural dynamic that l've briefly sketched above. Indeed, had it not done so, it likely would not be around any longer, would it?

All right, so that is the first sense in which I think movements must be understood by reference to institutions. Call it the "institutional continuum" argument - that movements are themselves proto-institutions in the process of an evolution into full-blown institutions.

The second sense in which movements must be understood by reference to institutions is less "ontological" and more "epistemological" in nature, at least initially. (I'll explain in a moment how this point morphs back into the first.) What I have in mind here is that an institution - in this case, a pre-existing, typically already "hard" institution - often provides or even constitutes a sort of a "focal point," or at the very least an "issuedefiner" or issue-sharpener, hence a kind of galvanizer, for a social movement. It provides the movement with its raison d'être or raisons d'être, so to speak. We can in fact even combine this point with the first one, discussed above, and say that movements often move either to become institutions or to oppose institutions, perhaps even to becoming institutions in order to oppose institutions. In all such cases, of course, the movement must be understood by reference to (one or more) institutions. Again a familiar example or two will make plain what I mean here. 
So, imagine, say, that on the one hand you've got a spontaneous outbreak of protest in Seattle in connection with a WTO meeting, or with an annual meeting of the IMF and World Bank staffs in Washington. Things begin with picketing, or perhaps throwing rocks through store windows. The rock-throwers do this because they're pretty certain that somehow there is something wrong with the world, and that the World Bank, the IMF, or the WTO has something to do with it, but they've not thought things through very well yet. They've not worked out a fully articulated affirmative agenda, and so they've not organized very fully. They only react to what several conspicuous, already existent, institutions do. Yet over time, what happens is that specific, concrete, well-defined and quite particular "issues" begin to recur in these protests - crushing sovereign debt or poor working conditions or environmental degradation, for example - and these become foci of our activists' protests. Once that happens, we have begun to move from "negative" complaint to "affirmative" advocacy, hence from spontaneous protest to "movement."

Now note that the particular issues I've mentioned, which come to define movements' affirmative agendas, quite often are themselves defined at least in part by the very institutions that first arouse the ire of the protesters. The "issues" are, for example, on the agenda for discussion at a particular round of WTO negotiations, or a particular IMF/IBRD annual meeting, or an ad hoc meeting held at the IMF headquarters in connection with, say, a financial crisis that has struck East Asia. The WTO places continued labor-advocated "protectionism" on its agenda. Or the IMF places sovereign debt on its agenda. The "movements," in response, place labor standards or debt-relief on their agendas and demand that the WTO and the IMF do so as well. In such cases the institution's own formulated agendas provide the occasion for the social movements themselves that react to those agendas to sharpen their own understandings of what they're about, of what actuates them, of what it is that the movements' members are ultimately concerned about and what it is that they are seeking by way of alternative.

So institutions are not only outcomes of movements as the latter move toward greater regularity and clarity in respect of aims and practices, as I tried to illustrate pursuant to my first point. They are also quite often occasioners, even partly definers, of those particular movements which then become institutions themselves. They effectively produce the materials that come to constitute the movements' goals and agendas. And the movements then either become institutions themselves, as per the first point above - the labor union and MoveOn examples - or gain places at the "tables" set in the institutions that occasion their development in the first place.

Were I adept in Continent-style philosophical history, I suppose I might almost be tempted to say that there is a sort of "dialectic" at work here: A set of interests gives rise to an institution - a mobilized set of resources and regularized set of practices geared toward advancing those interests. Some people are harmed by the successes or excesses of that 
institution, and so begin to react to it. They then coalesce into a movement, which itself then crystallizes into an institution, and the latter institution not accidentally develops into a sort of "antithesis" of the first institution. Or the antithetical movement is brought into the first institution, with the result that both institution and movement are changed, and so a "synthesis" of interests and values is worked. Maybe old Hegel and Collingwood were onto something.

I think we can sum up what I've been saying about the two interrelated senses in which movements and institutions are symbiotically related with a cute little metaphor: On the one hand, an institution can be viewed as a kind of transition belt, or drive shaft, for the effectuation of social movements' aims themselves. The institution is the way in which the movement's motion - all of the energies generated by the engine - can be translated into movement forward on the ground. On the other hand, and yet by the same token, the structural features of the drive shaft, or the mechanism of the institution itself, in turn constrain the design of and indeed structure the movement itself. We are able to imagine what it is that a movement wants - what it would move toward - only when we imagine what institution or set of institutions would embody and effectuate those wants. In short, then, again it would seem very clear that we cannot understand, let alone build or assist, movements or institutions without considering them in tandem, as essential complements of each other.

All right, that nearly completes what I have time to say. There is of course much more that could be said. But I'm rapidly approaching my time limit so I'll resist the temptation to say very much more. I would like very quickly to do one thing more before closing, however. I am a little concerned by what I take for an undercurrent of quietism or pessimism in Professor Miller's presentation. I doubt it's intended, but it's nonetheless easy to feel a little demoralized, I fear, upon first having our attentions called to the terrible stories that Dick has related in his paper. So by way of an antidote I would like to close on a brief note of hope. I'll tell one more story that I think will both buttress the observations I have already made, and will occasion some institution-fixing resolve, notwithstanding Dick's helpful reminders of how institutions have been co-opted and corrupted, typically by the most powerful nation-states, throughout history.

So imagine, if you would, a small island territory on which there are two classes of people, each of which is hereditarily determined and perpetuated: On the one hand, we find a rather small number of people who possess horses and suits of armor and lances and so forth, or are the spouses or children of such people. These people hold most of the land and live in large, castle-like dwellings. They don't work save in war time. In peace time they merely engage in intrigues or sporting contests, or fight over land with one another, using their horses and lances. Call them the "lords."

Now imagine that, at the same time, there is a very large number of those we'll call "peasants" or "serfs." Serfs can do nothing to support themselves save work the land of the lords. There's no land they can own. There 
are no resources available to them but their capacities to labor for lords. Now these serfs, not surprisingly, in consequence live under rather less advantaged life conditions than do the lords. This is best evidenced by the fact that many or most of them wish they'd been born lords, or fantasize about being lords, while few if any lords wish that they had been born serfs or fantasize about serf life.

Now suppose that we, with our present-day ethical commitments and sensibilities, step into this world and look around. Not surprisingly, we're a bit shocked. We judge that the continuation of this particular set of social arrangements will not do - it's unjust and degrading - and we wonder what we should do about it. Or perhaps we just ask ourselves what we should like to see happen here were we able to vote.

Should we establish a "global island" institution, or central government, in order to improve the prospects of the serfs by better distributing opportunity or life chances among persons whom we believe fundamentally to be ethical equals? Should we perhaps establish some such institution also in order to modulate the internecine warring of the lords, who so often are struggling with one another for territorial jurisdiction and harming serfs in the process? Won't the most powerful of these knights resist any attempt that we make to create a centralized government structure that modulates their warring and better distributes life prospects over the people who live on the island? Or won't they, if they don't resist or fail in preventing it, commandeer the apparatus of whatever institution we succeed in creating, in order to ensure that it actually works to advance their interests? Well, yes, of course they will.

But - and I think everything important here lies in the caveat - to answer "yes" to the questions just posed is not to say "no" to the need of the proposed island governance institution. Think about it: Over time the development of various productive technologies, modes of productive organization, and interpersonal economic relations on the "global island" we are imagining is much more than likely to issue in one or the other (or some mix) of the following developments: Development might lead to a greater immiseration of the serfs, such that that they grow increasingly desperate and ready to do just about anything to improve their lots. Or, as productive improvement and a gradual elevation of material living standards even among serfs occurs, the serfs will acquire the material wherewithal to develop enough sense of self, enough sense of personal dignity, enough sense of entitlement, enough sense of rights-bearingness to grow indignant at the difference between their life prospects and those of the lords. Either way, they are likely to act, to move, and at some point to move together.

Now in that connection note that in either of the two broad eventualities I've projected, the process of economic development will likely impart upon the serfs enough understanding of how to organize themselves probably in part by imitating and replicating the organizational modes that they have observed in productive enterprises - that they will now find themselves effectively able to move together in the direction of a more just 
distribution of resources and life prospects. They'll come to look like the labor movement as described earlier. And in all likelihood what that means, in turn, is that they will come gradually to compete with the lords for control of the centralized island governance institution, the desirability of which we are considering. And that form of competition will surely be preferable by all to outright "class war," will it not? Just as we've seen happen before.

Now I think that it's more or less obvious where I've been drawing my fanciful picture from. I've been recapitulating, in stylized, oversimplified form, the stories of many domestic polities-cum-economies. And the question presently before us is: Might we have reason to expect some analogous development on the global scale? Is there reason to suppose that the development-cum-institutional histories of our domestic polities can, should, or will be found replicable globally? I think that it's clear that there is. At the very least that's where the presumption should lie. Those who are skeptical of institutions as means to arrive at a more just political-cum-economic world order owe us; at the very least, some reason to expect the global case to differ from all of our "island" cases of the past several centuries. And if they cannot do that - as I suspect they cannot - the next question will be, how do we do it? How do we replicate globally the story that is so familiar domestically? I'll close with my brief provisional answer:

I suggest that we look for global analogues to the sorts of developments that have taken place over time within the domestic jurisdictions that now boast advanced economies and democratic polities. We should look for and identify such analogues in the international sphere, and then push forward at precisely those points. We should push, that is, for the kinds of economic improvement, the kinds of organizational improvement, and the kinds of situation-interpretive, theoretic capacity, required to enable the "global serfs" of today to accomplish globally what the "domestic serfs" of yesteryear accomplished in their own day and place. If I am right about this, then what I am advocating is, per Dick Miller, a global social movement, or a cluster of such movements. But by dint of that very fact, then, I also am advocating, for reasons that I've been at pains to elaborate, either new global institutions, or renewed global institutions, as well. And that, I believe, is precisely what we ought to hope for and move for. 